UDC 338.45: 616.2: 613.6.02

DOI: $10.21668 /$ health.risk/2018.4.08.eng

Read

online

\title{
GENETICALLY MODIFIED FOOD PRODUCTS: PECULIARITIES OF GENETIC IDENTIFICATION
}

\author{
G.F. Mukhammadiyeva ${ }^{1}$, D.O. Karimov ${ }^{1}$, O.V. Dolgikh ${ }^{2}$, A.V. Krivtsov ${ }^{2}$, A.A. Mazunina ${ }^{2}$ \\ ${ }^{1}$ Ufa Research Institute of Occupational Health and Human Ecology, 94 Stepan Kuvykin Str., Ufa, 450106, \\ Russian Federation \\ ${ }^{2}$ Federal Scientific Center for Medical and Preventive Health Risk Management Technologies, 82 Monastyrskaya Str., \\ Perm, 614045, Russian Federation
}

Our research goal was to perform a genetic analysis of food stuffs produced in Russia in order to determine whether genetically modified components, predominantly soya, occurred in them. We also set a task to draw up an optimal list of genetic modifiers for sausages and soya products; this list was to be applied as a tool for monitoring of undeclared GMO and for providing biological safety of food stuffs. We applied polymerase chain reaction in real-time mode to analyze certain food products (sausages and soya products); the analysis was to reveal genetically modified organisms. The task was to identify the following GMO genes: promoters (p35SCaMV, P-SSUAra, Ubil, ract1, hsp70, TA29 tobacco promoter), terminators (nos3, T-E9, T-g7, T-OCS), reporter genes (nptll, qHptFP308, bar, pat_10-P), bio-pesticides Bacillus Thuringensis (Bt) or Cry-toxins (CrylAb/Ac), reporter gene of $\beta$-glucuronidase (GUS-gene). Analysis of some sausage samples allowed us to identify the following GMO genes: CrylAb/Ac, P-FMV, P-nos, bar, gus_9-P, T-nos3, nptii, P-TA29, T-E9, T-g7, T-OCS. The research performed on food products revealed GMO in $56 \%$ of the analyzed sausage samples. Genetic modification of the analyzed food samples had its peculiarities; a set of identified genes that included promoter genes P-FMV, terminators (nos3, T-g7, T-OCS), CrylAb/Ac endotoxin, and a reporter of GMO bar was one of them. We recommend to use the following candidate genes for GMO contents in food products: Cry1Ab/Ac, P-FMV, P-nos, bar, gus_9-P, T-nos3, nptii, P-TA29, T-E9, T-g7, T-OCS. They all are evidence that genetic modifications took place and they all can be applied as marker genes for control over food products safety as per GMO contents criterion.

Key words: genetically modified organisms, genes, promoters, terminators, food products safety, polymerase chain reaction, DNA.

Nowadays genetically modified plants are grown in 28 countries; they are especially widely spread in the USA, Brazil, Argentina, India, and Canada. Soya, potato, corn, sugar beet, tomato, pumpkin, and rape are the most common cultures. Territories where genetically-modified plants are cultivated grow annually on average by $15-18 \%$. Every year more than 4,000 genetically modified cultures are tested in field tests. More than $60 \%$ of all the soya, $15 \%$ of all the potatoes, and $7 \%$ of all the corn produced in the world are genetically modified. Certain food products and dishes in the USA are at present produced only with genetic engineering technologies (for example, hamburgers, some salads, fried potatoes, etc.) [1-3].

In Russia transgenic cultures are not sown and grown for commercial use. There are only closed experimental fields that belong to various research centers. Some genetically modified cultures are grown in the

(C) Mukhammadiyeva G.F., Karimov D.O., Dolgikh O.V., Krivtsov A.V., Mazunina A.A., 2018

Guzel F. Mukhammadiyeva - Candidate of Biological Sciences, Head of the Molecular and Genetic Research Laboratory at Toxicology and Genetics Department (e-mail: ufniimt@mail.ru; tel.: +7 (347) 255-19-48; ORCID: https:// orcid.org/0000-0002-7456-4787).

Denis O. Karimov - Candidate of Medical Sciences, Head of the Department for Toxicology and Genetics (e-mail: karimovdo@gmail.com; tel.: + 7 (347) 255-19-48; ORCID: https://orcid.org/0000-0003-0039-6757).

Oleg V. Dolgikh - Doctor of Medical Sciences, Professor, Head of the Department for Immune-Biological Diagnostics (e-mail: oleg@fcrisk.ru; tel.: +7 (342) 236-39-30; ORCID: https://orcid.org/0000-0003-4860-3145).

Alexandr V. Krivtsov - Candidate of Medical Sciences, Head of the Immune-Genetics Laboratory (e-mail: oleg@fcrisk.ru; tel.: +7 (342) 236-39-30; ORCID: http://orcid.org/0000-0001-7986-0326).

Alena A. Mazunina - Junior Researcher at the Department for Immune-Biological Diagnostics (e-mail: oleg@fcrisk.ru; tel.: +7 (342) 236-39-30; ORCID: https://orcid.org/0000-0002-3579-4125). 
RF in order to test their biological safety; they are potatoes (Moscow and Moscow region, Tambov, Krasnodar, the Far East), soya (Krasnodar region), sugar beet (Moscow region, Tambov, Krasnodar region, the Far East), corn (Moscow region, Tambov, Krasnodar, the Far East). Transgenic potato is also grown to test various cultivars (in 18 regions), and transgenic sugar beet and soya are grown for further processing and use in Moscow region and on some other territories. As there is no ban on imports of transgenic food products into Russia and there is a considerable growth in their outputs in the world, such products are penetrating the Russian market in bigger and bigger quantities $[4,5]$.

A system of control over genetically modified organisms (GMO) existing in Russia is based on regulatory consequences detection (35S promoter and NOS terminator). However, genetic engineering development led to creation of the GMO that belong to the second generation and don't contain these regulatory consequences. Such cultures can potentially occur on the Russian food market and remain unidentified $[6,7]$.

It is vital to provide biological safety of food products, and to do this, it is necessary to identify genetically modified food sources that are not declared as well as GMO combinations. To develop an optimal diagnostic combination of genetic markers (test-systems) for each food product is a most significant task that needs to be solved for providing food products quality and safety. Real-time polymerase chain reaction is an efficient technique for nucleic acids analysis [8-12].

Our research goal was to perform genetic analysis of Russian food products quality in order to reveal possible occurrence of genetically modified components (predominantly soya) in them; to determine an optimal list of genetic markers for sausages and soya products that can help to monitor GMOs that are not declared and to provide food biological safety.
Data and methods. Overall, we analyzed 47 samples of food products that were sold in the Republic of Bashkortostan and Perm region trying to detect genes of both transgenic soya and non-transgenic one. Analyzed samples were mostly represented by sausage products and meat delicacies (45 samples) such as sausages (boiled, semismoked, and boiled-smoked ones), smoked products (ham and carbonade), pate. We also examined soya products (two samples): hard tofu and soya milk.

We quantitatively determined $35 \mathrm{~S}$ promoter of cauliflower mosaic virus in the genetically modified soya DNA; our determination included sampling and samples preparations; DNA extraction out of food products samples; DNA fragments amplification and hybridization-fluorescent detection that takes place directly during real-time polymerase chain reaction (PCR) with TaqMan probes.

In addition to quantitative determination of marker of cauliflower mosaic virus $35 \mathrm{~S}$ promoter we performed a qualitative real-time PCR for screening other genetic modification markers [13-20] that included ${ }^{1}$ :

- detection of promoters applied in plants transfection: p35SCaMV, Act1, Ubi1, hsp70, TA29 tobacco promoter; as a rule, these promoters are the most widely used by GMOs creators;

- detection of the following terminators: nos3, T-E9, T-g7, T-OCS;

- detection of the following reporter genes: nptll, hpt, bar, dhfr, epsps, cp4;

- detection of MARs.

DNA was extracted out of samples with "DNA-sorb-C" reagents kit (Rospotrebnadzor's Central Scientific Research Institute for Epidemiology, Moscow) aimed for DNA extraction out of clinical materials, food products, and animal forages.

Amplification was performed with "AmpliKvant GM soya-FL" reagents kit aimed for detecting the following DNA fragments:

${ }^{1}$ Marker genes in food products that are evidence of performed genetic modifications: Information and methodical letter No. 11132 dated December 14, 2017. - Perm: Rospotrebnadzor regional office in Perm region, 2017. 
a consequence of $35 \mathrm{~S}$ promoter of cauliflower mosaic virus (P-35S CamV) and endogenous control (soya EC), that is, a gene that is specific both for transgenic and non-transgenic soya. This approach allowed to detect soya DNA occurrence in an examined sample. Polymerase chain reaction was performed with Rotor-Gene Q device (Qiagen, Германия) and CFX96 Real Time System device with detection of reaction products in real time mode. To perform fluorescent detection of PCR products, we applied the following channels: FAM/Green - recombinant DNA of 35S promoter and JOE/Yellow soya gene (endogenous control).

According to GMO determination technique we simultaneously examined reference samples, a positive one (a sample with certain GM-content, soya line MON89788) and a negative one (a sample that was certainly without any GM-content).

Post-registration monitoring aimed at detecting GM-content included examination of documents issued for genetically modified sources (GMS), food products and control over GM-products marking.

Documents were examined via analyzing a list of GMS allowed for use in the RF and a list of GMS manufactured in the world in large quantities (the list includes 81 GMS, such as soya, corn, rape, potato, marrow, papaya, tomato, rice, sugar beet, muscat melon, flax, etc.). We controlled marking on each food product manufactured from GMS and containing more than $0.9 \%$ GMS components in its structure.
Results and discussion. We performed laboratory control of food products in order to accomplish qualitative and quantitative determination of GMS contents in accordance with the State Standards and $\mathrm{MG}^{2,3,4,5}$.

When we examined food products trying to identify genetically modified sources, we didn't reveal $35 \mathrm{~S}$ promoter of cauliflower mosaic virus in any sample. We detected nontransgenic soya in 38 out of 47 analyzed product samples; 5 out of 38 products samples didn't have any data on soya occurrence in their structure on a label.

Screening qualitative examinations of 16 food products (sausages, salami, summer sausage, servelat) revealed that some samples had genetically-modified ingredients (Figure).

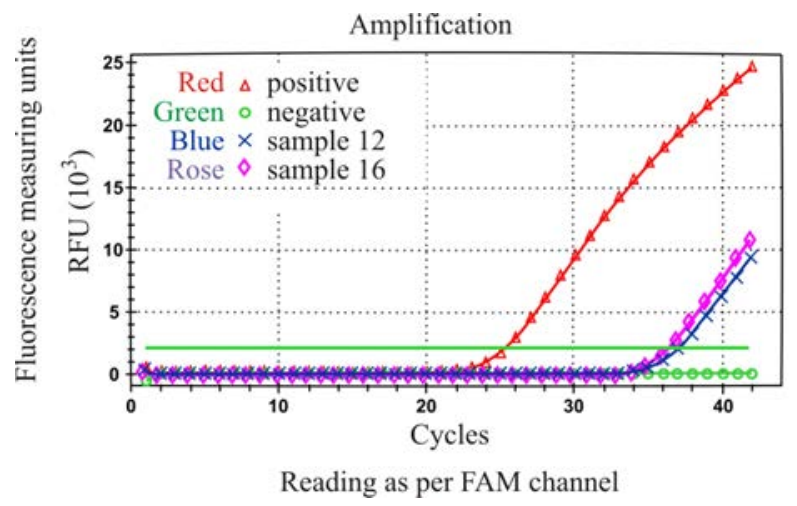

Figure. Polymerase chain reaction performed with CFX96 Real Time System device with detection of reaction products in real time mode. Amplification curves for 2 food products samples ("Bmketnaya" summer sausage and "Muskatnaya" boiled-smoked sausage) with P-FMV gene identification

\footnotetext{
${ }^{2}$ State Standard R 53244-2008. Food products. Analysis technique for detecting genetically modified organisms and products made of them. Techniques based on quantitative determination of nucleic acids [web-source] // KODEKS: an electronic fund of legal and reference documentation. - URL: http:// http://docs.cntd.ru/document/1200073607 (date of visit August 21, 2018).

${ }^{3}$ State Standard R ISO 21571-2014. Food products. Analysis technique for detecting genetically modified organisms and products made of them. Nucleic acid extraction [web-source] // KODEKS: an electronic fund of legal and reference documentation. - URL: http://docs.cntd.ru/document/1200114752 (date of visit August 15, 2018).

${ }^{4}$ MG 4.2.2304-07. Techniques for identification and quantitative determination of vegetable genetically modified organisms [web-source] // KODEKS: an electronic fund of legal and reference documentation. - URL: http://docs.cntd.ru/document/437120957 (date of visit August 06, 2018).

${ }^{5}$ MG 4.2.3390-16. Detection and identification of vegetable GMO with polymerase chain reaction in a matrix format [web-source] // KODEKS: an electronic fund of legal and reference documentation. - URL: http://docs.cntd.ru/document/456058289 (date of visit August 10, 2018).
} 
Table 1

Results of food products samples examination as per GMO contents

\begin{tabular}{|c|c|c|c|c|c|c|c|c|c|c|c|c|c|c|c|c|c|c|}
\hline $\begin{array}{c}\text { Samples } \\
\text { No. }\end{array}$ & $\begin{array}{l}\text { CaMV } \\
\text { P-35S }\end{array}$ & $\begin{array}{l}\text { CrylAb/ } \\
\text { Ac gene }\end{array}$ & P-FMV & P-nos & T-nos & bar & FMV34S & gus_9-P & qHptFP308 & NOS3-Taq & nptii & P-ract & P-SSuAra & P-TA29 & pat_10-P & T-E9 & T-g7 & T-OCS \\
\hline 1 & neg & neg & neg & neg & neg & neg & neg & neg & neg & neg & neg & neg & neg & neg & neg & neg & neg & neg \\
\hline 2 & neg & neg & neg & neg & neg & neg & neg & neg & neg & + & neg & neg & neg & neg & neg & neg & neg & neg \\
\hline 3 & neg & neg & neg & neg & neg & neg & neg & neg & neg & neg & neg & neg & neg & neg & neg & neg & neg & neg \\
\hline 4 & neg & neg & + & neg & neg & neg & neg & neg & neg & neg & + & neg & neg & neg & neg & neg & neg & neg \\
\hline 5 & neg & neg & neg & neg & neg & neg & neg & neg & neg & neg & neg & neg & neg & neg & neg & neg & neg & neg \\
\hline 6 & neg & + & neg & neg & neg & neg & neg & neg & neg & neg & neg & neg & neg & neg & neg & neg & neg & neg \\
\hline 7 & neg & neg & neg & neg & neg & neg & neg & neg & neg & neg & neg & neg & neg & neg & neg & neg & neg & neg \\
\hline 8 & neg & neg & neg & neg & neg & neg & neg & neg & neg & neg & neg & neg & neg & neg & neg & neg & neg & neg \\
\hline 9 & neg & neg & neg & neg & neg & neg & neg & neg & neg & neg & neg & neg & neg & neg & neg & neg & neg & neg \\
\hline 10 & neg & neg & neg & neg & neg & neg & neg & neg & neg & neg & neg & neg & neg & neg & neg & neg & neg & neg \\
\hline 11 & neg & + & neg & neg & neg & + & neg & neg & neg & neg & neg & neg & neg & neg & neg & neg & + & neg \\
\hline 12 & neg & neg & + & + & neg & neg & neg & neg & neg & + & neg & neg & neg & neg & neg & neg & neg & neg \\
\hline 13 & neg & neg & neg & neg & neg & neg & neg & neg & neg & + & neg & neg & neg & neg & neg & + & + & neg \\
\hline 14 & neg & neg & neg & neg & neg & + & neg & neg & neg & neg & neg & neg & neg & neg & neg & neg & neg & neg \\
\hline 15 & neg & neg & neg & neg & neg & neg & neg & neg & neg & neg & neg & neg & neg & + & neg & neg & neg & neg \\
\hline 16 & neg & neg & + & neg & neg & neg & neg & + & neg & neg & neg & neg & neg & neg & neg & neg & neg & neg \\
\hline $\mathrm{K}+$ & + & + & + & + & + & + & + & + & + & + & + & + & + & + & + & + & + & + \\
\hline K- & neg & neg & neg & neg & neg & neg & neg & neg & neg & neg & neg & neg & neg & neg & neg & neg & neg & neg \\
\hline
\end{tabular}

Our analysis of 16 food products samples, mostly variable sausages (Table 1), was aimed at identifying the following GMO genes: promoters (p35SCaMV, P-SSuAra, Ubi1, ract1, hsp70, tobacco TA29), terminators (nos3, T-E9, T-g7, T-OCS), reporter genes (nptll, qHptFP308, bar, pat_10-P), biopesticides genes Bacillus Thuringensis (Bt) or Cry-toxins (CrylAb/Ac), reporter gene of $\beta$-glucuronidase (GUS-gene); we revealed their absence in 7 analyzed food products samples against positive and negative reference samples. However, 9 sausage samples contained various GMO genes combinations such as Cry $1 \mathrm{Ab} / \mathrm{Ac}$, P-FMV, P-nos, bar, gus_9-P, T-nos3, nptii, P-TA29, T-E9, T-g7, T-OCS.

Conclusions. Our research didn't reveal any genetically modified soya as per a marker of $35 \mathrm{~S}$ promoter of cauliflower mosaic virus in food products. But at the same time we detected that a declared product structure of 5 sausage samples was false. Soya protein detected in their samples proves these food products have been falsified.
Post-registration monitoring aimed at GM-raw materials detection revealed occurrence of GMO markers that were not regulated in documents on standardization in $56 \%$ of analyzed sausage samples. Analysis of sausage samples allowed to identify candidate genes of genetically modified organisms, namely P-FMV promoter, terminators (nos3, T-g7, $\mathrm{T}-\mathrm{OCS}), \mathrm{Cry} 1 \mathrm{Ab} / \mathrm{Ac}$ endotoxin, bar reporter.

Such genes as Cry1Ab/Ac, P-FMV, P-nos, bar, gus_9-P, T-nos3, nptii, P-TA29, T-E9, T-g7, T-OCS can serve as an evidence that products containing them have been genetically modified. Genetic analysis of quality performed for products manufactured in Russia and aimed at detecting genetically modified components in them allows to recommend these genes to be applied as maker genes for control and providing food products safety as per GMO contents criterion.

Funding. The research was not granted any sponsor support.

Conflict of interests. The authors state there is no any conflict of interests. 


\section{References}

1. Bawa A.S., Anilakumar K.R. Genetically modified foods: safety, risks and public concerns-a review. J Food Sci. Technol., 2013, vol. 50, no. 6, pp. 1035-1046. DOI: 10.1007/s13197-012-0899-1

2. Wu Y., Li J., Wang Y., Li X., Li Y., Zhu L., Li J., Wu G. Development and application of a general plasmid reference material for GMO screening. Plasmid, 2016, vol. 87-88, pp. 28-36. DOI: 10.1016/j.plasmid.2016.08.001

3. James C. Global Status of Commercialized Biotech/GM Crops: 2014. ISAAA Brief. ISAAA: Ithaca, NY, 2014, no. 49, pp. 10-15.

4. Donnik I.M., Voronin B.A. Legal regulation of genetic engineering in agriculture in the Russian Federation. Agrarnyi vestnik Urala, 2017, vol. 156, no. 2, pp. 4 (in Russian).

5. Muratov A.A., Moskovenko N.V., Tikhonov S.L., Tikhonova N.V., Kurdyumov A.V. Normativno-pravovye aspekty regulirovaniya geneticheski modifitsirovannykh produktov na territorii Tamozhennogo soyuza [Regulatory aspects of the regulation of genetically modified products in the territory of the Customs Union]. Agroprodovol'stvennaya politika Rossii, 2017, vol. 63, no. 3, pp. 78-83 (in Russian).

6. Tutel'yan V.A. Obespechenie bezopasnosti genno-inzhenerno-modifitsirovannykh organizmov dlya proizvodstva pishchevykh produktov [Ensuring the safety of genetically engineered and modified organisms for food production]. Vestnik Rossiiskoi akademii nauk, 2017, vol. 87, no. 4, pp. 342-347. DOI: 10.7868/S0869587317040090 (in Russian).

7. Tyshko N.V. Control over genetically-modified sources of plant origin in food: scientific basis and methodical maintenance. Voprosy pitaniya, 2017, vol. 86, no. 5, pp. 29-33 (in Russian).

8. Chernysheva O.N., Sorokina E.Yu. Analytical methods for control of foodstuffs made from bioengineered plants. Voprosy pitaniya, 2013, vol. 82, no. 3, pp. 53-60 (in Russian).

9. Zaitseva N.V., Ulanova T.S., Dolgikh O.V., Nurislamova T.V., Mal'tseva O.A. Diagnostics of Early Changes in the Immune System Due to Low Concentration of N-Nitrosamines in the Blood. Bull Exp Biol Med., 2018, vol. 164, no. 3, P. 334-338. DOI: 10.1007/s10517-018-3984-2

10. Gerdes L., Busch U., Pecoraro S. GMOfinder - a GMO screening database. Food Analytical Methods, 2012, vol. 5, no. 6, pp. 1368-1376. DOI: 10.1007/s12161-012-9378-6

11. Morisset D., Novak P.K., Zupanič D., Gruden K., Lavrač N., Žel J. GMOseek: a user friendly tool for optimized GMO testing. BMC Bioinformatics, 2014, vol. 15, no. 1, pp. 258. DOI: 10.1186/1471-2105-15-258

12. Angers-Loustau A., Petrillo M., Bonfini L., Gatto F., Rosa S., Patak A., Kreysa J. JRC GMOMatrix: a web application to support Genetically Modified Organismsdetection strategies. BMC Bioinformatics, 2014, vol. 15, no. 1, pp. 417. DOI: 10.1186/s12859-014-0417-8

13. Alasaad N., Alzubi H., Kader A.A. Data in support of the detection of genetically modified organisms (GMOs) in food and feed samples. Data Brief, 2016, vol. 7, pp. 243-252. DOI: 10.1016/j.dib.2016.02.035

14. Debode F., Janssen E., Berben G. Development of 10 new screening PCR assays for GMO detection targeting promoters (pFMV, pNOS, pSSuAra, pTA29, pUbi, pRice actin) and terminators (t35S, tE9, tOCS, tg7). Eur Food Res Technol., 2013, vol. 236, no. 4, pp. 659-669. DOI: $10.1007 / \mathrm{s} 00217-013-1921-1$

15. Debode F., Janssen E., Bragard C., Berben G. Detection by real-time PCR and pyrosequencing of the cry $1 \mathrm{Ab}$ and cry $1 \mathrm{Ac}$ genes introduced in genetically modified (GM) constructs. Food Addit Contam Part A Chem Anal Control Expo Risk Assess, 2017, vol. 34, no. 8, pp. 1398-1409. DOI: 10.1080/19440049.2017.1317925

16. Dörries H.H., Remus I., Grönewald A., Grönewald C., Berghof-Jäger K. Development of a qualitative, multiplex real-time PCR kit for screening of genetically modified organisms (GMOs). Anal. Bioanal Chem., 2010, vol. 396, no. 6, pp. 2043-2054. DOI: 10.1007/s00216-009-3149-2

17. Gu K., Mao H., Yin Z. Production of marker-free transgenic Jatropha curcas expressing hybrid Bacillus thuringiensis $\delta$-endotoxin $\mathrm{Cry} 1 \mathrm{Ab} / 1 \mathrm{Ac}$ for resistance to larvae of tortrix moth (Archips micaceanus). Biotechnol Biofuels, 2014, vol. 7, pp. 68. DOI: 10.1186/1754-6834-7-68 
18. Randhawa G.J., Singh M. Multiplex, construct-specific, and real-time PCR-based analytical methods for Bt rice with cry1Ac gene. J. AOAC Int., 2012, vol. 95, no. 1, pp. 186-194.

19. Hernandez-Rodriguez C.S., Hernandez-Martinez P., Van Rie J., Escriche B., Ferre J. Shared midgut binding sites for Cry1A.105, Cry1Aa, Cry1Ab, Cry1Ac and Cry1Fa proteins from Bacillus thuringiensis in two important corn pests, Ostrinia nubilalis and Spodoptera frugiperda. PLoS One, 2013, vol. 8, no. 7, pp. e68164. DOI: 10.1371/journal.pone.0068164

20. Bahrdt C., Krech A.B., Wurz A., Wulff D. Validation of a newly developed hexaplex real-time PCR assay for screening for presence of GMOs in food, feed and seed. Anal Bioanal Chem., 2010, vol. 396, no. 6, pp. 2103-2112. DOI: 10.1007/s00216-009-3380-x

Mukhammadiyeva G.F., Karimov D.O., Dolgikh O.V., Krivtsov A.V., Mazunina A.A. Genetically modified food products: peculiarities of genetic identification. Health Risk Analysis, 2018, no. 4, pp. 75-80. DOI: 10.21668/health.risk/2018.4.08.eng

Received: 19.09 .2018

Accepted:

Published: 30.12.2018 